\title{
ZNAČAJ REVIZIJE JAVNOG SEKTORA ZA EFIKASNO UPRAVLJANJE JAVNIM FINANSIJAMA
}

\author{
Radoslav Sretenović, Ljubica Janković Andrijević \\ Državna revizorska institucija, Makenzijeva 41, Beograd, Srbija
}

\begin{abstract}
Apstrakt:
Revizija javnog sektora predstavlja jedan od najvažnijih kontrolnih mehanizama pravilnog i efikasnog trošenja javnih sredstava i upravljanja javnom imovinom, jer svojim sveukupnim aktivnostima uliva poverenje parlamentu, građanima i ostalim zainteresovanim stranama, čime doprinosi efikasnijem upravljanju javnim finansijama. Državna revizija je sastavni deo regulatornog sistema kojim se blagovremeno otkrivaju odstupanja od zakonitosti, efikasnosti, prihvaćenih standarda, efektivnosti i ekonomičnosti finansijskog upravljanja kako bi se preduzele neophodne mere u cilju sprečavanja negativnih posledica usled neodgovornog ponašanja izvršne vlasti. Suštinska funkcija državne revizije ogleda se u podržavanju i promovisanju javne odgovornosti za koju je neophodna institucionalna nezavisnost u skladu sa zahtevima Limske deklaracije. Pravni okvir za uspostavljanje državne revizije u Srbiji su Ustav Republike Srbije i Zakon o Državnoj revizorskoj instituciji, čime je obezbeđena nezavisnost državne revizije u Srbiji u skladu sa osnovnim postulatima Limske deklaracije. Pored pravnog, značajan je i profesionalni regulatorni okvir revizije javnog sektora i primena Međunarodnih standarda vrhovnih revizorskih institucija - ISSAI, koje objavljuje INTOSAI - Međunarodna organizacija vrhovnih revizorskih institucija, čiji je član od 2008. godine i Državna revizorska institucija Srbije. Aktivnosti i rezultati rada Državne revizorske institucije povećavali su se u pogledu opsega ali i preduzetih mera. Merenje doprinosa državne revizije stabilnosti finansijskog sistema zemlje obezbediće se primenom INTOSAI dokumenta „Okvir za merenje učinka vrhovnih revizorskih institucija“, koji predstavlja osnovu za izražavanje stalne važnosti vrhovnih revizorskih institucija za građane i druge zainteresovane strane, za procenu doprinosa boljem upravljanju javnim finansijama, većoj odgovornosti i borbi protiv korupcije. Najznačajniji rezultat dosadašnjeg rada Državne revizorske institucije Srbije predstavlja njen doprinos povećanju odgovornosti u trošenju javnih sredstava i upravljanju javnom imovinom, jer sama verovatnoća obavljanja revizije određenog entiteta povećava odgovornost pri trošenju državnog novca, smanjuje stepen zloupotrebe ovlašćenja i kršenja propisa.
\end{abstract}

\section{Ključne reči:}

državna revizija,

institucionalna nezavisnost,

javni sektor,

odgovornost u trošenju javnih sredstava,

međunarodni standardi vrhovnih revizorskih institucija.

\section{UVOD}

Sa razvojem parlamentarizma rasla je i potreba za efikasnom parlamentarnom kontrolom nad radom izvršne vlasti i sprečavanje zloupotrebe vlasti. Način parlamentarne kontrole i forma nadzora nad radom izvršne vlasti tokom istorije se menjao, kako u svetskim okvirima tako i u Srbiji. Kako savremena parlamentarna demokratija počiva na odgovornosti, to kontrolna funkcija parlamenta, po mišljenju mnogih autora, pored zakonodavne, postaje sve važnija. Kontrolnu funkciju parlament sprovodi neposredno (parlamentarni odbori, poslanička pitanja, javna slušanja, pitanja i interpelacija, specijalne komisije i anketni odbori) ili posredno preko nezavisnih državnih organa. Jedan od najmoćnijih instrumenata posredne parlamentarne kontrole je revizija javnog sektora koju obavlja Vrhovna revizorska institucija (VRI). VRI, kao najviši državni organ revizije javnih sredstava u svakoj zemlji pa i u Srbiji, obavljajući svoju ustavom i zakonom poverenu funkci- ju, pomaže parlamentu da na efikasniji način obavi svoju kontrolnu funkciju. Iako VRI u različitim zemljama funkcionišu u skladu sa različitim zakonskim nadležnostima i modelima, osnovni doprinos njihovog delovanja treba da bude podrška i promocija povećanja odgovornosti izvršne vlasti u trošenju javnih sredstava i upravljanju javnom imovinom.

\section{NEOPHODNOST USPOSTAVLJANJA DRŽAVNE REVIZIJE ZA EFIKASNIJE UPRAVLJANJE JAVNIM FINANSIJAMA}

Pravilno i efikasno korišćenje javnih sredstava predstavlja jedan od osnovnih preduslova za pravilno upravljanje javnim finansijama, kao i za racionalno i efektivno donošenje odluka nadležnih izvršnih vlasti u vezi sa trošenjem javnih sredstava i upravljanjem javnom imovinom. Jedan od najvažnijih kontrolnih mehanizama pravilnog i efikasnog korišćenja javnih sredstava u demokratski uređenim zemljama je državna 
revizija ili revizija javnog sektora. Kako u zemljama sa razvijenom tržišnom privredom i institucijama demokratskog parlamentarnog sistema, tako i u zemljama tranzicije, VRI ima značajnu ulogu u ostvarivanju stabilnosti finansijskog sistema zemlje. Svojim sveukupnim aktivnostima, a posebno izveštajima o reviziji, VRI treba da ulije poverenje parlamentu, građanima zemlje i ostalim zainteresovanim stranama.

Državna revizija nije sama sebi cilj, već je nerazdvojni deo regulatornog sistema pomoću kog treba da se otkriju odstupanja od prihvaćenih standarda i kršenja principa zakonitosti, efikasnosti, efektivnosti i ekonomičnosti upravljanja javnim finansijama dovoljno rano, da bi se omogućilo preduzimanje neophodnih korektivnih mera u cilju sprečavanja ili bar otežavanja nastanka negativnih posledica zbog neodgovornog ponašanja pojedinaca u vlasti.

Uloga državne revizije je da izvrši proveru i analizira protekle finansijske događaje, kao i postojanje nezakonitih procedura za trošenje javnih finansijskih sredstava i da kroz svoje izveštaje uveri parlament, vladu i građane u kvalitet izveštaja o trošenju novca poreskih obveznika, kao i o upravljanju imovinom i obavezama koje podležu javnoj kontroli. Suštinska funkcija državne revizije je da podržava i promoviše javnu odgovornost.

\section{DRŽAVNA REVIZIJA - NAJEFIKASNIJI INSTRUMENT PARLAMENTARNE KONTROLE}

Državna revizija se može definisati kao poseban vid parlamentarne kontrole zakonitosti trošenja javnih finansijskih sredstava i upravljanja javnom imovinom koju vrše nadležni državni organi i institucije. Stoga institucije koje obavljaju reviziju javnog sektora predstavljaju jedan od najvažnijih instrumenata parlamentarne kontrole. Da bi odgovorila zahtevima koji se pred nju postavljaju, VRI u svim zemljama, pa i u Srbiji mora da bude institucionalno nezavisna, što se reguliše ustavom i posebnim zakonom.

Veza između vrhovne revizorske institucije i parlamenta kao zakonodavnog tela države objašnjena je Limskom deklaracijom. U Deklaraciji se navodi da je nezavisnost VRI garantovana ustavom konkretne zemlje, kao i da je Vrhovna revizorska institucija ustavom ovlašćena da nezavisno izveštava parlament ili drugo kompetentno javno telo o svojim nalazima, kao i da objavi izveštaj (INTOSAI, 1977).

Međusobni odnos parlamenta i vrhovne revizorske institucije svake zemlje se zasniva na lancu odgovornosti. Vrhovna revizorska institucija je sredstvo kojim parlament nadzire vladu i javnu upravu. S druge strane, da bi izveštaji o reviziji imali efekta, vrhovna revizorska institucija oslanja se na sposobnost parlamenta da na osnovu tih izveštaja preduzima korake i da traži od vlade da položi račune o tome kako troši javna sredstva.

\section{PRAVNI I REGULATORNI OKVIR DRŽAVNE REVIZIJE U SRBIJI}

Kako u zemljama sa razvijenom tržišnom privredom i institucijama demokratskog parlamentarnog sistema, tako i u zemljama tranzicije, državna revizorska institucija ima značajnu ulogu u ostvarivanju stabilnosti finansijskog sistema zemlje, a svojim aktivnostima i izveštajima treba da ulije poverenje parlamentu, građanima zemlje i ostalim zainteresovanim subjektima.
Pravni okvir za uspostavljanje državne revizije u Srbiji su Ustav Republike Srbije(Službeni glasnik RS, 2006), Zakon o Državnoj revizorskoj instituciji, Zakon o budžetskom sistemu i odgovarajuća podzakonska akta.

Ustavom Republike Srbije definisana je uloga i položaj državne revizije u Srbiji, čijim odredbama je uređeno da je Državna revizorska institucija (DRI) najviši državni organ revizije javnih sredstava u Republici Srbiji, samostalna je i podleže nadzoru Narodne skupštine, kojoj i odgovara. Takođe je navedeno da se o Državnoj revizorskoj instituciji donosi poseban zakon. Time je postavljen temelj nezavisnosti državne revizije u Srbiji u skladu sa osnovnim postulatima Limske deklaracije. U Ustavu Republike Srbije dalje je definisano da izvršavanje svih budžeta kontroliše Državna revizorska institucija, a Narodna skupština razmatra predlog završnog računa budžeta po pribavljenom mišljenju Državne revizorske institucije. Time je jasno definisano da Narodna skupština može da razmatra predlog završnog računa budžeta tek po pribavljenom mišljenju Državne revizorske institucije.

Zakon o Državnoj revizorskoj instituciji je Narodna skupština Republike Srbije usvojila u novembru 2005. godine, kojim je takođe Državna revizorska institucija definisana kao najviši državni organ revizije javnih sredstava u Republici. Institucija je samostalan i nezavisan državni organ, ima svojstvo pravnog lica, sa sedištem u Beogradu, a poseduje i pečat u skladu sa zakonom. Zakonom o Državnoj revizorskoj instituciji uređena su pitanja: nadležnosti Institucije, njene organizacije i sastava, procesa izvođenja revizije, načina izveštavanja i druga pitanja značajna za rad Institucije, kao i prava i obaveze subjekata revizije.

Pored pravnog okvira, za efikasan rad Vrhovne revizorske institucije u obavljanju revizione nadležnosti, važan je i profesionalni regulatorni okvir, kojim su definisana opšte prihvaćena načela i pravila revizije javnog sektora u skladu sa odabranim međunarodno prihvaćenim standardima revizije. DRI Srbije se opredelila da obavlja revizionu nadležnost u skladu sa opšteprihvaćenim načelima i pravilima revizije definisane u INTOSAI (International Organization of Supreme Audit Institutions) okviru profesionalnih standarda i smernica relevantnih za potrebe njenih članica. Državna revizorska institucija Srbije je postala punopravna članica Međunarodne organizacije vrhovnih revizorskih institucija (INTOSAI) u novembru 2008. godine i ovlašćena je da prevodi i objavljuje Međunarodne standarde vrhovnih revizorskih institucija - ISSAI (The International Standards of Supreme Audit Institutions).

Međunarodna organizacija vrhovnih revizorskih institucija INTOSAI je autonomna, nezavisna i nepolitička organizacija koja pruža institucionalni okvir vrhovnim revizorskim institucijama za unapređenje razvoja i prenošenje znanja, globalno unapređenje državne revizije i jačanje profesionalnih kapaciteta, položaja i uticaja vrhovnih revizorskih institucija - članica. Vrhovne revizorske institucije imaju glavnu ulogu u reviziji državnih računa i poslovanja izvršnih državnih organa, kao i u promovisanju stabilnog finansijskog upravljanja i odgovornosti u svojim vladama.

Kao profesionalna organizacija vrhovnih revizorskih institucija i međunarodno priznati lider u reviziji javnog sektora, INTOSAI objavljuje Međunarodne standarde vrhovnih revizorskih institucija -ISSAI (The International Standards of Supreme Audit Institutions). Međunarodni standardi vrhovnih revizorskih institucija ISSAI određuju osnovne principe i preduslove za pravilno delovanje i profesionalno ponašanje 
vrhovnih revizijskih institucija, kao i osnovne principe i smernice za reviziju u javnom sektoru.

\section{EFEKTI RADA I DOPRINOS DRŽAVNE REVIZIJE POVEĆANJU ODGOVORNOSTI U TROŠENJU JAVNIH SREDSTAVA I UPRAVLJANJU JAVNOM IMOVINOM}

Revizija javnog sektora, kao poseban vid aktivnosti parlamentarne kontrole, usmerena je na kontrolu izveštaja koje izvršna vlast podnosi parlamentu o trošenju javnih sredstava i upravljanju javnom imovinom, zatim na zakonitosti rada tih organa, kao i na ekonomičnost, efikasnost i efektivnost prikupljanja i trošenja finansijskih javnih sredstava i upravljanju javnom imovinom i obavezama, koje su u nadležnosti državnih organa i institucija.

Prema cilju revizije javnog sektora ${ }^{1}$ se mogu svrstati u tri osnovne grupe:

- revizija finansijskih izveštaja (financial audit),

- revizija usklađenosti poslovanja s propisima (compliance audit),

- revizija svrsishodnosti (performance audit).

Revizija finansijskih izveštaja i revizija usklađenosti poslovanja s propisima u praksi se preklapaju, s obzirom da u reviziji javnog sektora skoro nije moguće obaviti kvalitetnu finansijsku reviziju bez revizije usklađenosti, zbog specifičnosti kako predmeta revizije tako i subjekata revizije čije je poslovanje uređeno brojnim propisima.

Skoro u svim zemljama VRI vrše finansijsku reviziju, veliki broj primenjuje integrisan princip finansijske revizije i revizije pravilnosti poslovanja, dok manji broj vrši reviziju svrsishodnosti.

Revizija svrsishodnosti je novijeg datuma i mnoge zemlje još uvek ne sprovode ovu vrstu revizije. Međutim u nekim zemljama VRI sprovode samo reviziju svrsishodnosti, kao što je slučaj u Sjedinjenim Američkim Državama. Kancelarija za odgovornu vlast $(\mathrm{GAO})^{2}$ je od 1970 . godine potpuno napustila koncept finansijske revizije i od tada vrši samo reviziju svrsishodnosti za potrebe Kongresa SAD.

DRI Srbije istovremeno, vrši finansijsku reviziju i reviziju usklađenosti, pri čemu se sastavljaju dva izveštaja i izražavaju dva mišljenja - posebno mišljenje o finansijskim izveštajima i posebno mišljenje o pravilnosti poslovanja. Od 2013. godine vrši se i revizija svrsishodnosti.

Analizom podataka iz godišnjih izveštaja, koje je DRI podnosila Narodnoj skupštini u periodu od njenog suštinskog uspostavljanja 2009. godine, kada je objavljen prvi izveštaj o reviziji Završnog računa budžeta Republike Srbije za 2008. godinu, zaključno sa 2014. godinom, može se zaključiti da su aktivnosti i efekti rada DRI rasli. U navedenom periodu izdato je ukupno 266 izveštaja o sprovedenim revizijama subjekata javnog sektora, od kojih je u 13,86\% izveštaja izraženo pozitivno mišljenje, u 77,53\% mišljenje sa rezervom, u 8,61\% uzdržavajuće mišljenje i nijedno negativno mišljenje.

1 Postoji podela i prema predmetu revizije: revizija budžeta i programa usmerenih na ciljeve, revizija ugovora (audit of contracts), revizija javnih nabavki (audit of procurement), revizija privatizacije, (audit of privatisation), revizija javnog duga države (audit of public debt), revizija okruženja (environmental audit) i dr.

2 The U.S. Government Accountability Office
U cilju otklanjanja utvrđenih nepravilnosti u postupku revizije subjektima revizije je data 2.341 preporuka, od kojih je 8 preporuka dato u formi inicijative za izmenu zakona i podzakonskih akata, o čemu se Odboru za finansije Narodne skupštine dostavlja detaljan poseban izveštaj.

Nakon dužeg perioda nepostojanja kontrole trošenja javnih sredstava u Srbiji, uspostavljanje Državne revizorske institucije i njene dosadašnje aktivnosti u znatnoj meri su doprinele efikasnijoj parlamentarnoj kontroli izvršne vlasti u trošenju javnih sredstava i upravljanju javnom imovinom kao i podizanju efikasnosti u upravljanju javnim finansijama.

Tabela 1. Pregled izvršenih revizija po godinama

\begin{tabular}{ccc}
\hline Godina & $\begin{array}{c}\text { Broj } \\
\text { izveštaja/subjekata }\end{array}$ & $\begin{array}{c}\text { Broj } \\
\text { datih preporuka }\end{array}$ \\
\hline 2010 & 10 & 16 \\
\hline 2011 & 47 & 466 \\
\hline 2012 & 143 & 778 \\
\hline 2013 & 66 & 1.081 \\
\hline 2014 & 128 & 1.489 \\
\hline Ukupno & 266 & 2.341 \\
\hline
\end{tabular}

Posebno se ukazuje na specifičnost aktivnosti DRI Srbije, nesvojstvenu za prirodu same revizije, koja je zbog propisane obaveze u Zakonu o državnoj revizorskoj instituciji ${ }^{3}$ da se u slučajevima kad se u postupku revizije otkriju materijalno značajne radnje, koje ukazuju na postojanje elemenata prekršaja ili krivičnog dela u istom periodu nadležnim organima podnela 711 prijava protiv 871 odgovornih lica, od kojih se 574 odnosi na zahteve za pokretanje prekršajnog postupka, 75 na prijave za privredni prestup, a 62 na krivične prijave.

Rast aktivnosti DRI od osnivanja do danas jasno pokazuje grafički prikaz koeficijenta efikasnosti rada po subjektu revizije $^{4}$ (Slika 1)..$^{5}$

Najznačajniji rezultat dosadašnjeg rada Državne revizorske institucije, koji se ne meri brojem i sadržajem podnetih izveštaja, datih preporuka subjektima revizije za otklanjanje revizijom utvrđenih nepravilnosti ili brojem podnetih prijava, je doprinos povećanju odgovornosti u trošenju javnih sredstava, upravljanju javnom imovinom i podizanju efikasnosti u upravljanju javnim finansijama. Sama činjenica da je državna revizija uspostavljena u Srbiji, i da postoji verovatnoća da će biti vršena revizija određenog entiteta, povećava pažnju odgovornih lica u trošenju državnog novca, a time i njihovu odgovornost. Nepostojanje nadzora i kontrole trošenja javnih sredstava u znatnoj meri povećava prostor za zloupotrebe i kršenje propisa i odluka.

Merenju doprinosa državne revizije parlamentarnoj kontroli i stabilnosti finansijskog sistema zemlje, doprinosi primena INTOSAI metodologije koji obezbeđuje objektivnu osnovu za izražavanje stalne važnosti VRI za građane i druge zainteresovane strane, za procenu doprinosa boljem upravljanju

3 „SL. glasnik RS”, br. 101/2005, 54/2007 и 36/2010.

4 Koeficijenat efikasnosti rada po subjektu revizije dobijen kao odnos broja subjekata revizije i broja zaposlenih

5 Podaci iz internih evidencija DRI. 
Koeficijent efikasnosti rada po subjektu revizije

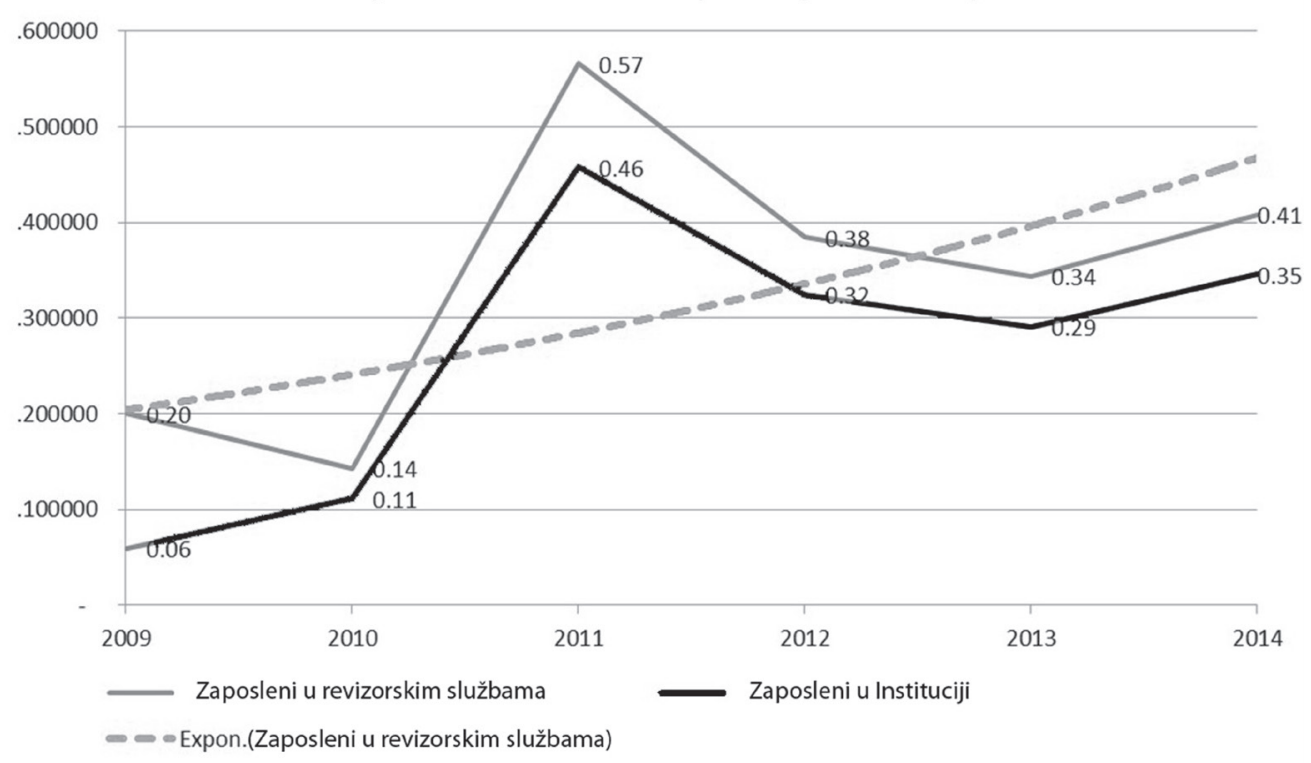

Slika 1. Koeficijent efikasnosti rada po subjektu revizije

javnim finansijama, većoj odgovornosti, kao i doprinosu naporima u borbi protiv korupcije. Primenom ove metodologije i odgovarajućih dokaza moguće je proceniti da li neka VRI obavlja svoje zadatke u skladu sa dobrom međunarodnom praksom, i da li je sposobna da identifikuje sopstvene snage i slabosti.

Okvir za merenje učinka vrhovnih revizorskih institucija SAI PMF (State Audit Institution Performance Measurement Framework) pripremila je INTOSAI Radna grupa o vrednosti i koristi od VRI, a prema odluci donetoj na Kongresu INTOSAI u Južnoj Africi 2010. Ova verzija je zvanični nacrt za izlaganje koji će biti predmet opsežnih konsultacija i usmeravanja unutar i van INTOSAI tokom 2013-2016. Pripremljen je na osnovu iskustava iz prvih pilot verzija nacrta 2.0 sa malim brojem SAI (State Audit Istitution - Vrhovnih revizorskih institucija) i komentara velikog broja aktera primljenih u periodu od septembra do decembra 2012. Cilj je da se ovaj nacrt posle daljih konsultacija i usmeravanja preda na odobrenje na Kongresu INTOSAI 2016. godine. Na kongresu INTOSAI održanom u Kini u oktobru mesecu 2013. godine razmotreni su rezultati prvih pilot verzija sa određenim brojem SAI i doneta odluka da će se Okvir za merenje učinka vrhovnih revizorskih institucija usvojiti na Kongresu INTOSAI 2016. godine, kao zvaničan obavezujući dokument za sve članice INTOSAI.

\section{ZAKLJUČAK}

U skladu sa ciljevima izloženim u nacrtu ISSAI X: Vrednost i koristi od VRI - pozitivan uticaj na živote građana, SAI PMF će takođe obezbediti za VRI objektivnu osnovu za pokazivanje njihove stalne važnosti za građane i druge zainteresovane strane. On teži da proceni doprinos VRI snažnom rukovođenju javnim finansijama, dobrom upravljanju i odgovornosti, kao i napore u borbi protiv korupcije. To će dati Vrhovnoj revizorskoj instituciji priliku da postane model organizacije, koja svojim primerom promoviše transparentnost i odgovornost, kroz kredibilno javno izveštavanje o svom radu.

\section{LITERATURA}

Andrić, M., \& Jakšić, D. (2001). Uloga državne revizije u procesu harmonizacije. V simpozijum SRRS, Banja Vrućica.

Andrić, M., Krsmanović, B., \& Jakšić, D. (2004). Revizija: teorija i praksa. Subotica: Ekonomski fakultet.

Beetham, D. (2006). Parlament and Democracy in the 21st Century. New York: Interparlamentry Union.

GAO. (2004). Kongresni protokoli Kancelarija za odgovornu vlast Sjedinjenih Američkih Država (GAO) od 16. jula 2004. godine. Preuzeto sa http://www.gao.gov/images/US-GAO.

Hayes, R., Schilder, A. Dassen, R., \& Wallage, P. (2002). Principi revizije: Medunarodna perspektiva. Banja Luka: SRRRS.

IFAC. (2014). International Standard of Auditing. International Federation of Accountants. Preuzeto sa http://www.iaasb.org/ clarity-center/clarified-standards

IMF. (2001). Government Finance Statistics Manual 2001 (GFSM 2001) International Monetary Fund. Preuzeto sa https://www. imf.org/external/pubs/ft/gfs/manual/

INTOSAI. (1977). The Lima Declaration of Guidelines on Auditing - Approved at IXth Congress of INTOSAI, Lima/Peru 1977. Preuzeto sa http://www.intosai.org/issai-executivesummaries/view/article/issai-1-the-lima-declaration.html

ISSAI. (2015). The International Standards of Supreme Audit Institutions (ISSAI). International Organization of Supreme Audit Institutions. Preuzeto sa http://www.issai.org

Janković Andrijević, Lj. (2012). Magistarski rad „Pravni i profesionalni regulatorni okvir za nastanak i razvoj državne revizije u Srbiji. Novi Sad: Privredna akademija.

Milojević, A., \& Trklja, M. (2000). Javne finansije. Srpsko Sarajevo: Ekonomski fakultet.

Službeni glasnik RS. (2006). Ustav Republike Srbije. Službeni glasnik RS, br. 83/2006, 98/2006.

Službeni glasnik RS. (2010). Zakon o Državnoj revizorskoj instituciji. Službeni glasnik RS, br. 101/2005, 54/2007 i 36/2010.

Stojanović, R. (2010). Međunarodni standardi finansijskog izveštavanja: objavljeni do 1. januara 2009: IAS- International Accounting Standards. Beograd: Savez računovođa i revizora Srbije

Vidaković, S. (2009). Revizija osnova kompetentnosti, kredibiliteta, poverenja. Novi Sad: Mala knjiga. 
THE IMPORTANCE OF PUBLIC SECTOR AUDIT FOR EFFICIENT PUBLIC FINANCIAL MANAGEMENT

\section{Abstract:}

Public sector audit is one of the most important control mechanisms for proper and efficient use of public funds and public property management, as its overall activities give confidence to the government, citizens and other stakeholders, and thus contribute to more efficient public financial management. State audit is an integral part of the regulatory system that enables early detecting of discrepancies concerning the legal forms, efficacy, valid standards, efficiency and cost-effectiveness of financial management so as to implement necessary corrective measures to prevent or impede adverse effects resulting from improper actions of executive bodies. The main role of the state audit is to support and promote public responsibility that requires institutional independence according to the Lima Declaration. The legal framework for establishing the state audit in Serbia are the Constitution of the Republic of Serbia and Law on the State Audit Institution, which guarantees independence of the state audit in Serbia in accordance with the main postulates of Lima Declaration. There is also the professional regulatory framework for public sector audit and application of the International Standards of Supreme Auditing Institutions - ISSAI, issued by INTOSAI International organization of supreme auditing institutions, whose memeber is also the Serbian State Audit Institution since 2008. The activities and results of the State Audit Institution are of great importance. Measurement of the contribution of the state audit to stability of the financial system of the country could be achieved through implementation of INTOSAI document ' Framework for measuring performance of the state audit institutions', which is the basis for highlighting the long-term importance of the Supreme Audit Institution for the citizens and other interested parties, as well as for measuring its contribution to better public financial management, greater responsibility and successful struggle against coruption. The most significant result of the State Audit Institution in Serbia is its contribution to enhancing the responsibility for conducting the audit of an entity, increasing the responsibility in allocation of public funds, and reducing the abuse of authorisations and breach of valid regulations.

\section{Key words:}

state audit,

institutional indepndence,

public sector,

responsibility for allocation of public funds,

International Standards of Supreme Audit Institutions (ISSAI) 